\title{
Previously undescribed dental arrangement among electric knifefishes, with comments on the taxonomic and conservation status of Tembeassu marauna Triques (Otophysi: Gymnotiformes: Apteronotidae)
}

\author{
Ricardo Campos-da-Paz
}

Recent study of the type-material of Tembeassu marauna, a poorly-known species currently represented in collections only by its holotype (male) and paratypes (male and female), all collected forty years ago at the Ilha Solteira reservoir area, upper Paraná river region, revealed an unique pattern of dental arrangement among members of the order Gymnotiformes. This autapomorphic condition refers to a patch of around 15 elongate conical, extra teeth associated to soft tissue, and disposed inside the mouth on a restricted area at the roof of oral cavity and located just in front of the premaxillary bones (although clearly apart from those). Besides this obvious feature, two additional conditions are recognized as possibly unique for T. marauna, which refer to the conspicuous "fleshy" (that is, not presenting subjacent bony structures) anterior elongations of the upper and lower jaws. Some additional osteological features identified on radiographs taken from the type material belonging to that species are presented. A brief discussion is furnished, indicating that the recent inclusion of the nominal Tembeassu marauna in Apteronotus La Cépède is not supported by currently available evidence. Thus, it is herein suggested that the species is kept in it own separate genus within the Apteronotidae. Finally, it is argued that T. marauna possibly represents an endangered species at the upper Paraná river region.

Estudo recente do material-tipo de Tembeassu marauna Triques, espécie pouco conhecida e atualmente representada em coleções apenas por seu holótipo (macho) e dois parátipos (macho e fêmea), todos coletados há quarenta anos na área do reservatório de Ilha Solteira, região do alto rio Paraná, revelou um padrão de dentição único dentre membros da ordem Gymnotiformes. Esta condição autapomórfica refere-se a um conjunto de cerca de 15 dentes extras, cônicos e alongados, associados ao tecido mole e dispostos no interior da boca em uma área restrita do teto da cavidade oral, posicionados logo à frente dos ossos premaxilares, porém claramente dissociados dos mesmos. Além desta característica óbvia, são também reconhecidos como caracteres supostamente únicos de T. marauna os conspícuos prolongamentos carnosos (isto é, que não são suportados por estruturas ósseas subjacentes) das extremidades anteriores da maxila e da mandíbula. Algumas outras características osteológicas identificadas em radiografias do material tipo da espécie são apresentadas. Uma discussão breve é fornecida, indicando que a inclusão da espécies nominal Tembeassu marauna em Apteronotus La Cépède não se sustenta em evidências atualmente disponíveis. Assim, sugere-se que esta espécie deve ser mantida em seu próprio gênero separado dentro de Apteronotidae. Finalmente, são apresentados argumentos no sentido de reconhecer T. marauna como uma espécie possivelmente ameaçada de extinção na região alto rio Paraná.

Key words: Apteronotus, gymnotiforms, mouth, osteology, teeth, upper Paraná.

\section{Introduction}

The poorly-known monotypic gymnotiform genus Tembeassu Triques, 1998 (family Apteronotidae) was originally established on the basis of a short descriptive work, in which a single externally visible morphological feature was furnished to diagnose that new taxon from other gymnotiform genera, namely, the presence of "an enlarged fleshy lateral lobe on the chin" (Triques, 1998: 5, fig. 3; Fig. 1). Considerations of phylogenetic relationships of Tembeassu, as well as

Setor de Ictiologia/Departamento de Vertebrados, Museu Nacional, Quinta da Boa Vista s/n, São Cristovão, 20940-040 Rio de Janeiro, RJ, Brazil. 
informations concerning aspects of internal anatomy of the holotype and two paratypes of the nominal T. marauna Triques, 1998 (the only specimens so far referred to that species), were not presented in that contribution.

In that work, Triques (1998) stated that available specimens of Tembeassu marauna exhibit "a few teeth present on a patch over the pre-maxillary region and also on the palatine region" (1998:7). Recent detailed study of the holotype and paratypes of T. marauna showed that, although those specimens do have teeth on the premaxillary bones, they have no teeth at all at the so-called "palatine region". More precisely, examination of radiographs taken from the above mentioned types demonstrated that those fishes, on the other hand, exhibit a patch of "extra teeth" entirely located inside their mouths, loosely attached to the soft tissue in front of (and apart from) the premaxillary bones. Such unusual condition represents an unique previously undescribed feature among gymnotiform fishes, which it is briefly described below.

Recently, Albert (2001) included Tembeassu marauna in a monophyletic apteronotid assemblage he named as the "Apteronotus sensu stricto". Despite the fact that no mentions at all regarding T. marauna have been provided in the main text of that contribution, that species was eventually listed as Apteronotus marauna in the "Appendix 4" (Albert, 2001: 126), a position subsequently followed by Albert (2003: 499). It will be argued below that most, if not all, character conditions defining Albert's Apteronotus s. s. do not in fact apply to Tembeassu, and as a result currently available evidence for including the nominal Tembeassu marauna in Apteronotus La Cépède is actually weak. It is, then, herein recommended that the species should be kept in its own separate genus until a more detailed and objective investigation dealing with its phylogenetic relationships is provided. Finally, a note on the conservation status of Tembeassu marauna is also presented.

\section{Material and Methods}

Holotype and paratypes of Tembeassu marauna, as well as some specimens representative of additional apteronotid species from the upper Paraná and São Francisco river systems (see below), were $\mathrm{x}$-rayed with aid of a Faxitron Digital X-Ray System, Model MX-20, belonging to the Ichthyology Section of the Museu de Zoologia da Universidade de São Paulo (MZUSP; São Paulo, Brazil). Digital radiographs obtained from the above mentioned type material were subsequently inverted for a more clear presentation (see Figs. 2-5). Bone terminology follows Campos-da-Paz (2000). Counts of vertebrae include those four anterior ones ("C1-C4") associated to the Weberian apparatus; the first anterior vertebra bearing a fully-developed neural spine is " $\mathrm{C} 5$ ". The term "transitional vertebrae" refers to those precaudal vertebrae not directly associated to ribs, and also not bearing fully-developed hemal spines (as well as displaced hemal spines [DHS]; see Albert, 2001). Additional apteronotid material used in osteology comparisons was cleared and counterstained for bone

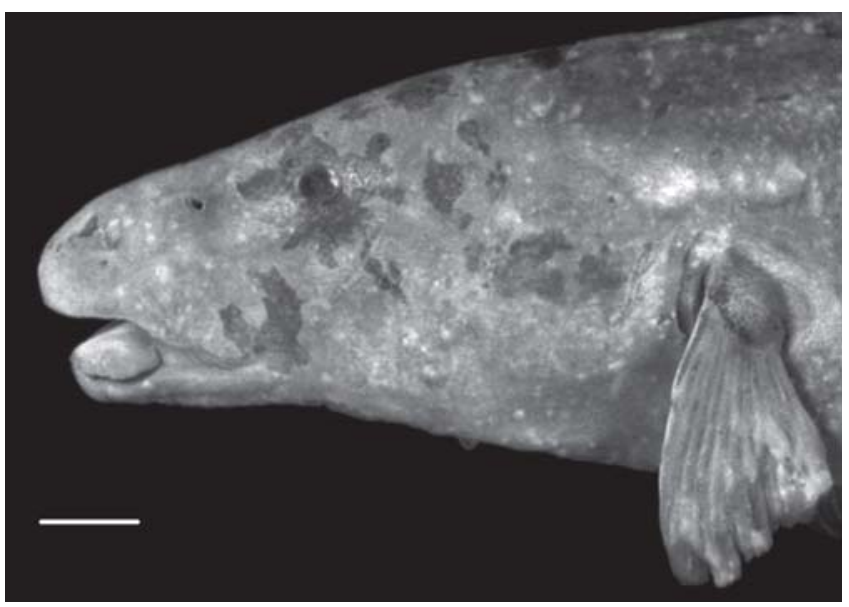

Fig. 1. Holotype of Tembeassu marauna (MZUSP 48510), left side of head. Scale bar $\sim 5 \mathrm{~mm}$.

and cartilage based on methods outlined by Taylor \& Van Dyke (1985), and it is primarily housed at the MZUSP and at the Museu Nacional (MNRJ; Rio de Janeiro, Brazil). Most apteronotid specimens used in overall comparisons, other than osteology observations, are listed in Campos-da-Paz (1997).

\section{Results}

Radiographs depicting the anterior region of the skull of holotype (MZUSP 48510) and male paratype (MZUSP 23090) of Tembeassu marauna are exhibited on Figs. 2 and 3, respectively. A number of relevant skeletal structures are evident, including the anteriorly-placed patch of extra teeth (indicated by arrows), as well as the conspicuous "fleshy", or "boneless" (that is, not supported by subjacent bony structures), forward extensions of both the upper and lower jaws (in front of the anterior limits of premaxillary and dentary bones).

Details of the upper jaw region (from lateral and dorsal views), and a closer observation of anteriorly-placed extra teeth are shown in radiographs taken from the female paratype of the above species (MZUSP 23090; Figs. 4 and 5).

Inspection of both Figs. 2 and 3 demonstrates that teeth at the oral cavity of Tembeassu marauna are only associated to the premaxillary and dentary bones, and to the soft tissue (possibly cartilage) forming part of the "boneless" anterior extension of the upper jaw. No teeth are actually present at the "palatine region" of the mouth (for instance, on the endopterygoid bone; see below).

Additional evident osteological information obtained from radiographs taken from the types of Tembeassu marauna, useful either for phylogenetic and taxonomic purposes, are as follows: mesethmoid narrow and rounded anteriorly, its dorsal profile straight; well-developed rounded (somewhat elongate) premaxilla, with approximately 15 well-developed elongate conical teeth irregularly covering the entire ventral surface of that bone; around 30 well-developed elongate conical teeth (posteriorly directed) all along outer margin of 


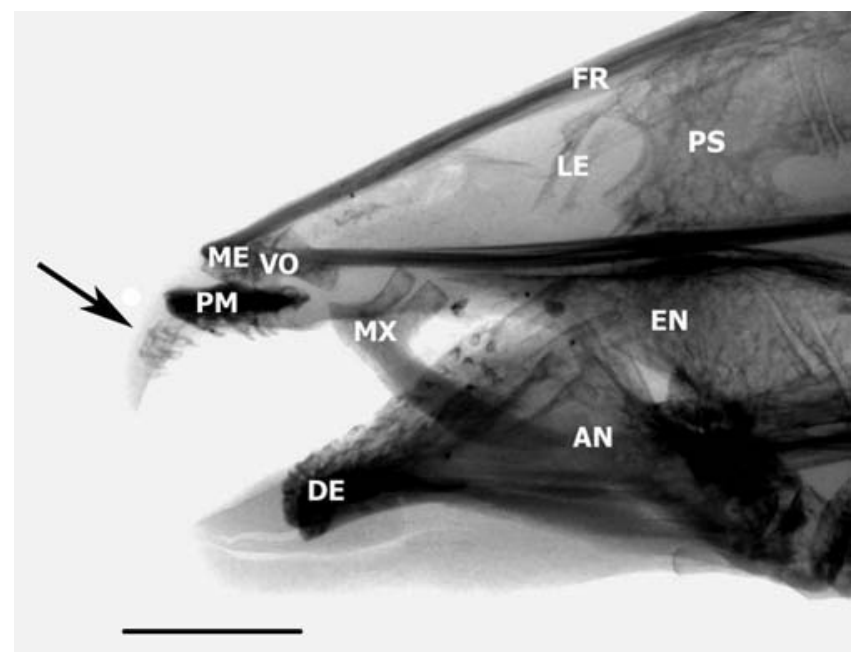

Fig. 2. Radiograph (inverted) showing skeletal structures at the anterior portion of head of the holotype of Tembeassu marauna (MZUSP 48510). Arrow at left indicates the patch of extra teeth inside the mouth (roof of the oral cavity), loosely attached to soft tissue in front of the premaxillary bones (PM). Additional abbreviations are as follows: $\mathrm{AN}=$ anguloarticular; $\mathrm{DE}=$ dentary $; \mathrm{EN}=$ endopterygoid $; \mathrm{FR}=$ frontal $; \mathrm{LE}=$ lateral ethmoid; $\mathrm{ME}=$ mesethmoid; $\mathrm{MX}=$ maxilla; $\mathrm{PS}=$ pterosphenoid; $\mathrm{VO}=$ vomer (ventral ethmoid). Scale bar $\sim 5 \mathrm{~mm}$.

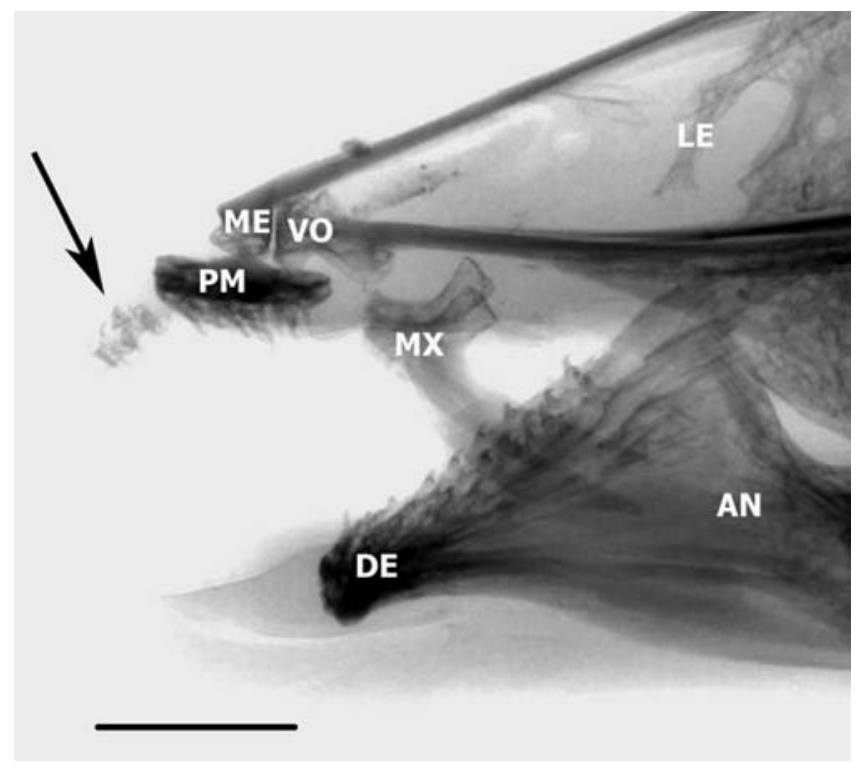

Fig. 3. Radiograph (inverted) showing the left side of the anterior region of head of the male paratype of Tembeassu marauna (MZUSP 23090), also exhibiting the conspicuous forward extension of the fleshy ("boneless") portions of the upper and lower jaws, in front of the premaxillary (PM) and dentary bones (DE), respectively. Additional abbreviations as in Figure 2. Arrow at left indicates the patch of extra teeth loosely attached to soft tissue at the roof of oral cavity, in front of the premaxillary bones, at the anteriorly extended portion of the upper jaw. Scale bar $\sim 5 \mathrm{~mm}$. dentary bone, arranged in two rows throughout most of its length (posterior from symphysis); well-developed, somewhat narrow, edentulous maxilla, with anterior area of descending blade not conspicuously developed; lateral ethmoids present; well-developed, V-shaped (anteriorly truncated), anterior portion of vomer (= ventral ethmoid); and well-developed edentulous endopterygoid bone, without any dorsally-located ascending process contacting neurocranium. Holotype and paratypes all with 18 precaudal vertebrae (including three transitional vertebrae).

\section{Discussion}

As already quoted above, Triques (1998:7) stated that the types of Tembeassu marauna have "a few teeth present on a patch over the pre-maxillary region and also on the palatine region". Premaxillary bones of Tembeassu marauna do, in fact, bear numerous teeth (around 15). Concerning the "palatine region", some general issues need to be raised. First, it can be noticed that there is no ectopterygoid bone in known gymnotiforms, nor an ossified autopalatine ("palatine ossification" of Fink \& Fink, 1981) in known apteronotids. Also, the palatine cartilage is not associated to any kind of teeth in members of that order. It is uncertain then if, when referring to "teeth on the palatine region", Triques could be in fact meaning, for instance, "teeth on the endopterygoid" (actually an unusual condition among apteronotid fishes in general, apparently only currently noticed in Platyurosternarchus MagoLeccia). Radiographs of the holotype and paratypes of $T$. marauna (see Figs. 2 and 3) show that those specimens have no teeth at all on the endopterygoid. One possible conclusion is that Triques (1998) misidentified those anteriorly-placed extra teeth inside the mouth of specimens of T. marauna as premaxillary teeth, and then recognized the actual premaxillary teeth, located a little more posteriorly in the oral cavity, as "palatine teeth".

Teeth observed inside the anterior region of the oral cavity of Tembeassu marauna (Figs. 2-5) are loosely attached to soft tissue just in front of the premaxillary bones, and constitute an unique feature not previously noticed in any gymnotiform fish being, thus, presently considered an autapomorphy of that species. Counts made on the radiographs of the holotype and paratypes of T. marauna reveal that 10-15 elongate conical teeth (similar in shape to the adjacent premaxillary teeth) are distributed in that restricted area, including a few, not fully-developed, smaller ones (Fig. 5). Those teeth are not directly associated to the premaxillary bones in the available specimens (all adults, which were identified, after inspection of their gonads, as being two males [the holotype and a paratype], and one female [remaining paratype]).

The extra teeth of Tembeassu marauna develop at a conspicuous anterior extension of the upper jaw (Figs. 2-5), an additional apparently unique condition also not currently described in any remaining apteronotid. The discovery of juveniles belonging to that species would be helpful in demon- 


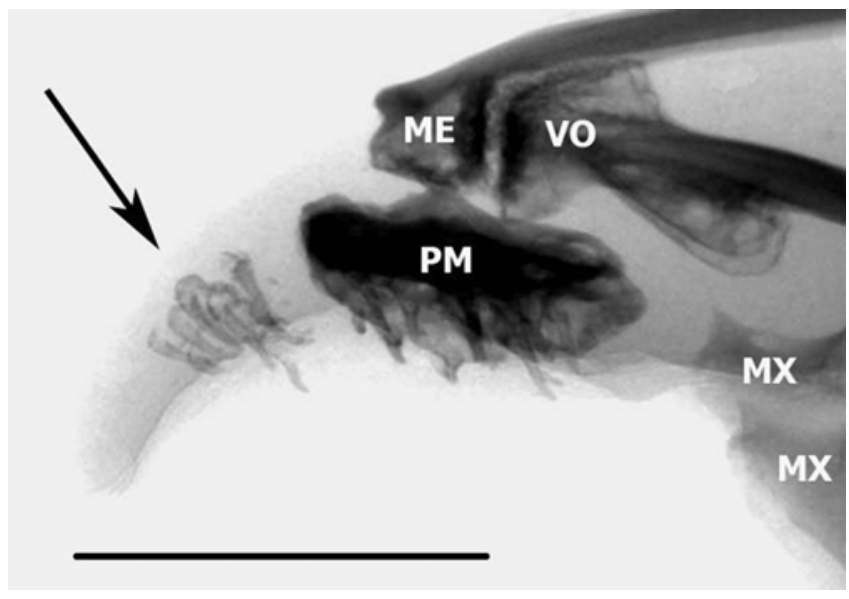

Fig. 4. Radiograph (inverted) showing a detail of the left side of the upper jaw region of the female paratype of Tembeassu marauna (MZUSP 23090). Arrow at left indicates the patch of extra teeth at the anteriorly extended "boneless" portion of snout, loosely attached to soft tissue in front of the premaxillary bones (PM). Additional abbreviations as in Figure 2 (above; both maxillary bones noticed). Scale bar $\sim 5 \mathrm{~mm}$.

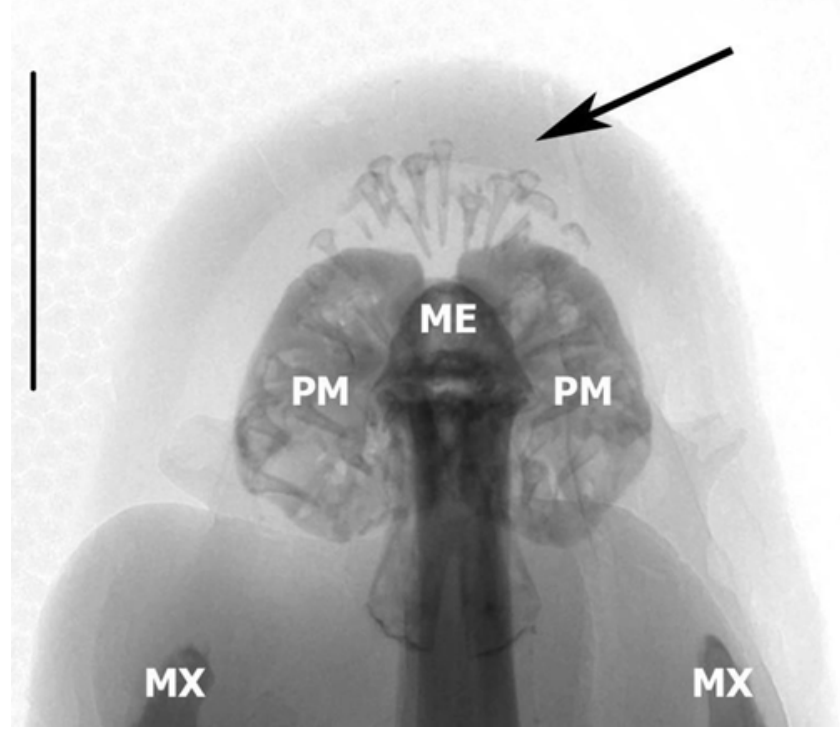

Fig. 5. Radiograph (inverted) exhibiting a dorsal view of the anteriormost region of snout of the female paratype of Tembeassu marauna (MZUSP 23090). Arrow at right indicates the patch of extra teeth at the anteriorly extended "boneless" portion of snout, loosely attached to soft tissue in front of the mesethmoid $(\mathrm{ME})$ and premaxillary bones $(\mathrm{PM})(\mathrm{MX}=$ maxillary bones). Scale bar $\sim 5 \mathrm{~mm}$.

strating whether those extra teeth are in fact independent from the premaxillary bones at all ages or, otherwise, if some kind of closer association could be observed in early forms (that is, a progressive dissociation between these structures occuring during the ontogenetic development of the individuals, possibly related to an also expected progressive development of the anterior "boneless" portion of the upper jaw).
Well-developed teeth (sometimes including some extra teeth), located on the anteriormost region of the snout and mouth region are currently described for a few other apteronotid taxa (for example, genus Sternarchogiton Eigenmann, 1905). However, in those groups, these structures always also occur outside the mouth, are clearly associated to the (sometimes modified and enlarged) premaxillary bones, and are only observed in sexually dimorphic males [see, for instance, Mago-Leccia, 1994: 146, figs. 40.A and 40.B; note that the nominal Oedemognathus exodon Myers, 1936 is currently considered a synonym of Sternarchogiton nattereri (Steindachner, 1868); Albert, 2003: 500]. Well-developed teeth (also sometimes including some extra teeth) are also observed at the chin region (i.e., associated to the dentary bone) of sexually dimorphic males belonging to some species of Sternarchorhynchus Castelnau (C. Cox-Fernandes, and C. D. de Santana, pers. comm.; again, also in Sternarchogiton). According to C. Cox-Fernandes (pers. comm.), those teeth located outside the mouth of dimorphic males belonging to the above mentioned groups are perhaps used for individual disputes for territory and/or females.

In short, the extra teeth observed in all available specimens of Tembeassu marauna are restricted to the conspicuous forward extension of the anterior portion of the roof of the oral cavity, and are not distributed on the outer region of mouth. Moreover, since they are noticed in both males in females, that condition does not represent a case of sexual dimorphism. It is suggested that this kind of unusual dental arrangement is possibly related to feeding habits (a stomach content analysis is currently in course and will be presented elsewhere).

Extra teeth (or accessory teeth) attached to soft tissue inside the oral cavity, and in a position similar to those observed in Tembeassu marauna, are known, for instance, from species included in the advanced siluriform trichomycterid subfamily Stegophilinae (M. C. C. de Pinna, pers. comm.). Those teeth in such species are, however, specialized concerning their shape, and are used for obtaining food items (mainly mucus and scales). An additional interesting observation concerning most adult stegophilines is that a number of those extra teeth eventually coalesce and associate themselves together through their bases (in a "fusion" process), forming a single median dentigerous bony element named the "median premaxilla".

An additional interesting feature observed in the radiographs taken from the type material of Tembeassu marauna refers to the conspicuous forward "boneless" extension of the lower jaw (chin region; somewhat similar to that elongation pattern noticed above concerning the upper jaw; see Figs. 2-3), in front of the anterior limits of the dentary bone (dentary symphysis). This additional previously undescribed unique enlargement condition (i.e., compared to known gymnotiform fishes) appears to be somehow related to that above mentioned enlargement of the "fleshy lateral lobe on the chin" described by Triques (1998). As previously noticed above regarding derived conditions associated to the for- 
ward extension of the upper jaw, discovery of juveniles of $T$. marauna will certainly be helpful to understanding the developmental patterns leading to that final (derived) presentation of the lower jaw morphology.

Campos-da-Paz (1997; character 6) stated that the presence of a "small lateral fold of skin at the anterior portion of the lower lip" would represent a synapomorphy of the Apteronotidae. On these grounds, it is suggested herein that the "enlarged fleshy lateral lobe on the chin" pointed out by Triques as the single diagnostic feature separating Tembeassu from remaining gymnotiforms represents an extreme condition derived from that previous one mentioned above and, as a result, it is homologous to it.

\section{Comments on the taxonomic status of Tembeassu Triques.}

Albert (2001) defined his "Apteronotus sensu stricto" (equivalent to Albert's recent concept [2003] of Apteronotus La Cépède) as an apteronotid monophyletic assemblage whose members exhibit the following five putative synapomorphies: 1) color of body surface deep brown or black; 2) premaxilla gracile, scroll-shaped in adults, with 2 or fewer teeth; 3) anterior limb of anguloarticular shorter than posterior limb; 4) surface of cranial bones smooth and laminar, not pitted; and 5) behavioral capacity to inhabit small rivers, swamps, estuaries, or upland streams (Albert, 2001:76).

Considering these above mentioned derived conditions, and regarding the type material of Tembeassu marauna, it can be first argued that neither the holotype, nor the paratypes, are in fact "deep brown or black" but, instead, they exhibit a mostly brown to light brow, or even greyish-brown colouration. Second, as for instance observed in Fig. 5 (above), the premaxilla in T. marauna is not gracile, nor scrollshaped, and bears far more than 2 teeth. The anterior and posterior limbs of anguloarticular are not precisely noticed in the available radiographs of the type material of T. marauna, and this character condition is herein considered uncertain regarding that species. Further, a detailed observation of radiographs shows that at least part of the cranial bones do have their sufaces "pitted" (or exhibiting a general reticulated appearance; see, for example, the endopterygoid and pterosphenoid bones in Figs. 2 and 3). Finally, currently available material of Tembeassu is known only from a large river (the rio Paraná), apparently from a deep area in that system (so far only obtained in a collection from a coffer-dam; see below), and there are no indications at all that the species is commonly distributed in shallow-water habitats. Thus, that fifth character condition above obviously does not apply to T. marauma.

From the above, it is concluded herein that the nominal species Tembeassu marauna should not be referred to Apteronotus (as proposed by Albert, 2003), and its phylogenetic relationships within the Apteronotidae remain uncertain. I believe that the best taxonomic solution at this point, admittedly a conservative one, would be to keep it in its own separate genus until a more detailed and objective study on this subjet is presented.

\section{Note on the conservation status of Tembeassu marauna.}

Although only three specimens of Tembeassu marauna are known to date (all collected from a coffer-dam, during the building process of the Ilha Solteira reservoir, upper rio Paraná system, Mato Grosso do Sul and São Paulo States [Brazil], in 1965), available evidence indicates that individuals of that species apparently demonstrate that same habitat preference, for instance, as the also apteronotid Sternarchorhynchus britskii Campos-da-Paz (holotype of this latter species [MZUSP 52923] collected at that same area above), that is, those deeper portions of large rivers (a behaviour also observed in other specialized groups belonging to the Apteronotidae throughout South America). If this eventually proves to be true, the actual distribution of T. marauna will only be confidently estimated when the Paraná river and other large river systems in the Neotropical Region have been more completely sampled at all depths.

Sternarchorhynchus britskii was recently included in the Brazilian "National List of Threatened Aquatic Invertebrates and Fish Species" ("Lista Nacional das Espécies de Invertebrados Aquáticos e Peixes Ameaçadas de Extinção"). Although somewhat "rare" compared to other gymnotiform groups endemic to the upper Paraná region (specially members of the Gymnotidae and Sternopygidae), that species is currently known from localities other than the Ilha Solteira reservoir limits, in some smaller sub-systems at that large area (for instance, the Grande river system between the Minas Gerais and São Paulo States in Brazil). Campos-da-Paz (2000) suggested that the main food items (insect larvae) searched by that species are associated to a special kind of channel river substrate.

Those preferred habitats of S. britskii in the upper Paraná system have been strongly modified during the last decades, specially because of the introduction of several medium- to large-sized dams at different sections of the upper Paraná, a situation that was perhaps decisive for its inclusion in that above mentioned list. Since T. marauna apparently also inhabits those same locations, that species possibly represents itself an endangered one in that region, and should deserve that same conservation status as S. britskii (above). Moreover, considering the present discussion, it can be also noticed that, according to available information, new specimens of T. marauna apparently have not been collected elsewhere during the past forty years.

X-rayed type-material of Tembeassu marauna. BRAZIL. MZUSP 48510 (holotype), Mato Grosso do Sul State (original record refer to "São Paulo State"), upper rio Paraná drainage, rio Paraná (cofferdam [="ensecadeira"]), Ilha Solteira, approx. 20³0'S 5100'W: "Expedição do Departamento de Zoologia", Sep 1965. MZUSP 23090 (2, paratypes; collected with the holotype).

Additional x-rayed apteronotid material. BRAZIL. Apteronotus brasiliensis, MZUSP 73674 (1), Minas Gerais State, rio das Velhas, Curvelo, Xavante Farm, 1853'22"S 4408'15"W; 30 Jun 2000. Apteronotus sp., MZUSP 22512 (2), Mato Grosso do Sul State, upper rio Paraná drainage, rio Paraná (in front to Jupiá), Três Lagoas; 
15-23 Sep 1962. Apteronotus sp. MZUSP 62682 (2), São Paulo State, rio Paraíba drainage (locality error; possibly rio Paraná drainage), "Cachoeira" (ibid.). "Apteronotus" sp., MZUSP 23094 (5), Mato Grosso do Sul State, upper rio Paraná drainage, rio Paraná, Ilha Solteira, approx. $20^{\circ} 15^{\prime} \mathrm{S} 51^{\circ} 07^{\prime} \mathrm{W}$. "Sternarchella" curvioperculata, MZUSP 24465 (8), Mato Grosso State, upper rio Paraná drainage, rio Paraná (coffer-dam [="ensecadeira"], right margin), Ilha Solteira, approx. 19³5'S 56 27'W; "Excursão MZUSP”.

\section{Acknowledgements}

For access to material housed at MZUSP, including types of Tembeassu marauna, as well as logistical and technical support, and all other kinds of assistance, I am deeply indebted to Mário C. C. de Pinna, Heraldo A. Britski, Cristiano L. R. Moreira, Maria Isabel P. F. Landim, and Fabio Di Dario. Cristiano L. R. Moreira prepared the excellent radiographs included in the present contribution, and also kindly provided me with the photograph depicted in Fig. 1. I sincerely thank all colleagues at the MNRJ for their continuous support and assistance during my time as a post-doctoral fellow at that institution, especially Paulo A. Buckup, Gustavo W. A. Nunan, Marcelo R. de Britto, and Miriam S. Ghazzi. I also would like to thank Carlos David C. de Santana, Cristina CoxFernandes, James S. Albert, José Alves-Gomes, and William Crampton for sharing their knowledge concerning gymnotiform fishes in general, and also to two anonymous reviewers for their helpful comments and encouragement. Special thanks are also due to the Conselho Nacional de Desenvolvimento Científico e Tecnológico (CNPq) (Brazilian "National Council of Technological and Scientific Development") for a Post-Doctoral scholarship (Proc. No. 150336/20039). This paper is dedicated to Francisco Mago-Leccia.

\section{Literature Cited}

Albert, J. S. 2001. Species diversity and phylogenetic systematics of American knifefishes (Gymnotiformes, Teleostei). Miscellaneous Publications, Museum of Zoology, University of Michigan, 190:1-127.

Albert, J. S. 2003. Family Apteronotidae. Pp. 497-502. In: Reis, R. E., S. O. Kullander \& C. J. Ferraris, Jr. (Orgs.). Check List of the Freshwater Fishes of South and Central America. Edipucrs, Porto Alegre, 729 p.

Campos-da-Paz, R. 1997. Sistemática e taxonomia dos peixes elétricos das bacias dos rios Paraguai, Paraná e São Francisco, com notas sobre espécies presentes em rios costeiros do leste do Brasil (Teleostei: Ostariophysi: Gymnotiformes). Unpublished Ph. D. Dissertation, Universidade de São Paulo, São Paulo. 336 p.

Campos-da-Paz, R. 2000. On Sternarchorhynchus Castelnau: a South American electric knifefish, with descriptions of two new species (Ostariophysi: Gymnotiformes: Apteronotidae). Copeia, 2000:521-535.

Fink, S. V. \& W. L. Fink. 1981. Interrelationships of the ostariophysan fishes. Zoological Journal of the Linnean Society, 72:297-353.

Mago-Leccia, F. 1994. Electric fishes of the continental waters of America. Peces eléctricos de las aguas continentales de America. Fundación para el Desarrollo de las Ciencias Fisicas, Matematicas y Naturales (FUDECI), Biblioteca de la Academia de Ciencias Fisicas, Matematicas y Naturales, 229:1-225.

Taylor, R. \& C. C. Van Dyke. 1985. Revised procedures for staining and clearing small fishes and other vertebrates for bone and cartilage study. Cybium, 9:107-119.

Triques, M. L. 1998. Tembeassu marauna, new genus and species of electrogenic neotropical fish (Ostariophysi: Gymnotiformes: Apteronotidae). Revue française d'Aquariologie, 25:5-10. 